\title{
Enzyme-based electrochemical biosensors for food safety: a review
}

\author{
This article was published in the following Dove Press journal: \\ Nanobiosensors in Disease Diagnosis \\ 20 April 2016 \\ Number of times this article has been viewed
}

\author{
Harish Kumar \\ Rani Neelam \\ Electrochemistry Laboratory, \\ Department of Chemistry, \\ Chaudhary Devi Lal University, \\ Sirsa, Haryana, India
}

Correspondence: Harish Kumar Electrochemistry Laboratory, Department of Chemistry, Chaudhary Devi Lal University, Barnala Road, Near Mini Secretariat, Sirsa, Haryana 125 055, India Email harimoudgil I@gmail.com

\begin{abstract}
In recent years, food storage environment safety has been a major concern for food and health scientists. There is growing interest in electrochemical biosensors due to their high sensitivity and rapid response. The aim of this review article is to provide details regarding the development of enzyme-based electrochemical biosensors, and their use in the detection of a range of chemical and biological compounds in the food industry. We have focused on the basic principle, generation, classification, and application of electrochemical biosensors for food safety.
\end{abstract}

Keywords: electrochemical biosensor, bioreceptor, transducer, food-borne pathogens

\section{Introduction}

Food is a basic requirement of all human beings. Microorganisms such as pathogens, viruses, and bacterium are present in food, and partially or completely destroy the nutritional quality of food. Food-borne pathogens are a major threat to food safety. Pathogens can cause serious diseases that lead to $40 \%$ of the total 50 million deaths annually in the world. ${ }^{1}$ Food production, preservation, and prevention from chemical and microbial contamination, insect infection, and pathogenic contamination have become very essential in today's fast life style. ${ }^{2}$ For food safety and quality, various conventional analytical techniques are used such as polymerase chain reaction, culture- and colony-based methods, and immunology-based methods. These methods are more time consuming, laborious, and require a well-trained person. There is an increasing demand for developing a fast and sensitive technique to monitor food-borne pathogens.

A biosensor is a device or instrument that comprises a biological sensing material combined with a chemical or physical transducer, which converts a chemical or biological signal into an electrical signal. ${ }^{3}$ A typical biosensor is shown in Figure 1.

Biosensors have many applications in food (pathogen, additives), environmental monitoring (toxic pollution), clinical diagnoses (glucose in blood, cholesterol), and biodefense (biowarfare) due to their selectivity, sensitivity, stability, and quick response time. ${ }^{4}$ The capacity of a biosensor is enhanced by using nanomaterials such as carbon nanotubes (CNTs), nanowires, magnetic nanoparticles (NPs), nanorods, and quantum dots. ${ }^{5}$ These nanomaterials have a high capacity for charge transfer and make the sensor suitable for higher sensitivity values and lower detection limits. ${ }^{5}$ Keeping in mind the above facts, an extensive literature survey was carried out on electrochemical biosensors for food safety. This review provides information regarding the history, classification, and application of electrochemical biosensors for food safety. 


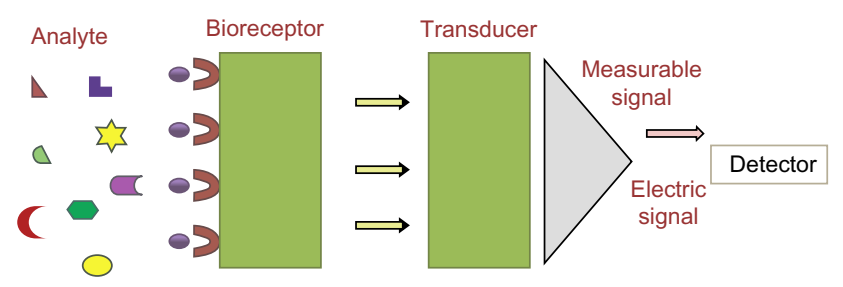

Figure I A typical representation of a biosensor.

\section{Historical perspective}

The first glucose sensor was proposed by Clark and Lyon ${ }^{6}$ from Cincinnati Hospital in 1962. An oxygen electrode is entrapped in a thin layer of glucose oxidase (GOx) via a semipermeable dialysis membrane in which the oxygen consumption is monitored by the enzyme-catalyzed reaction. ${ }^{7}$

$$
\text { Glucose }+\mathrm{O}_{2} \stackrel{\text { GOx }}{\longrightarrow} \text { Gluconic acid }+\mathrm{H}_{2} \mathrm{O}_{2}
$$

Updike and Hicks ${ }^{8}$ modified the oxygen background by using two working oxygen electrodes in which one contained the enzyme and the other calculated the differential current. In 1969, Guilbault and Montalvo reported the first enzymebased potentiometric biosensor in which urease enzyme was immobilized on an ammonia electrode for the detection of urea. In 1973, Guilbault and Lubrano developed an amperometric enzyme electrode for the determination of glucose in blood samples and monitored the amount of liberated hydrogen peroxide. ${ }^{9}$

$$
2 \mathrm{H}_{2} \mathrm{O}_{2} \rightarrow \mathrm{O}_{2}+2 \mathrm{H}^{+}+2 \mathrm{e}^{-}
$$

\section{First-generation glucose biosensor}

The first-generation glucose biosensor is based on the use of natural oxygen and determination of the amount of liberated hydrogen peroxide. ${ }^{7,10}$ Glucose is converted into gluconolactone by GOx with simultaneous reduction of flavin adenine dincleotide (FAD) to $\mathrm{FADH}_{2}$, and finally, FAD would be regenerated as $\mathrm{FADH}_{2}$ to produce
$\mathrm{H}_{2} \mathrm{O}_{2}$. When voltage is applied, the oxidation of $\mathrm{H}_{2} \mathrm{O}_{2}$ takes place, which results in an electric signal. ${ }^{7}$ Several shortcomings, such as oxygen dependence are present in the first-generation biosensor.

$$
\begin{aligned}
\text { GOx }(\mathrm{FAD})+\text { Glucose } \rightarrow & \text { GOx }\left(\mathrm{FADH}_{2}\right) \\
& + \text { Gluconolactone }
\end{aligned}
$$

The active site and the FAD prosthetic group are buried deep within the enzyme, which restricts the diffusion of reagents, ${ }^{11}$ and second, there is limited solubility of $\mathrm{O}_{2}$ in aqueous media. ${ }^{10,12}$ Marcus theory shows that the electron transfer decreases exponentially with increasing distance. ${ }^{13,14}$ The diagrammatic representation of the first-generation glucose biosensor is shown in Figure 2.

\section{Second-generation glucose biosensor}

The first-generation biosensor needs further improvement due to the oxygen deficiency. The limitation of the first-generation glucose biosensor is removed by replacing the oxygen with redox (electron) mediators that carry electrons from enzyme to electrode. ${ }^{15,16}$ Mediators like poly(vinylpyridiene) and poly(vinylimidazole) combine with osmium complex electron and minimize the distance between the center of polymers and FAD of enzyme, which results in the rapid response of sensor and high current. The diagrammatic representation of the second-generation glucose biosensor is shown in Figure 3. The second-generation biosensor has the defect of leaching the mediator. ${ }^{12,17}$ Hence, there was a demand for the production of the third-generation biosensor.

$$
\begin{aligned}
& \text { GOx-FADH }_{2}+2 \text { Mediator }_{(\mathrm{Ox})} \\
& \rightarrow \text { GOx-FAD }+2 \text { Mediator }_{(\mathrm{Red})}+2 \mathrm{H}^{+} \\
& 2 \text { Mediator }_{(\mathrm{Red})} \rightarrow 2 \text { Mediator }_{(\mathrm{Ox})}+2 \mathrm{e}^{-}
\end{aligned}
$$

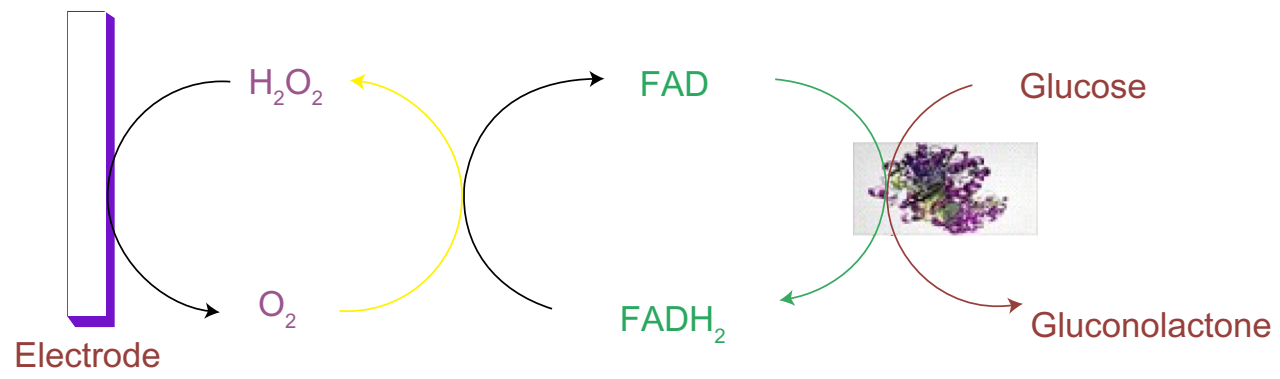

Figure 2 Diagrammatic representation of the first-generation of a glucose biosensor. Abbreviation: FAD, flavin adenine dinucleotide. 


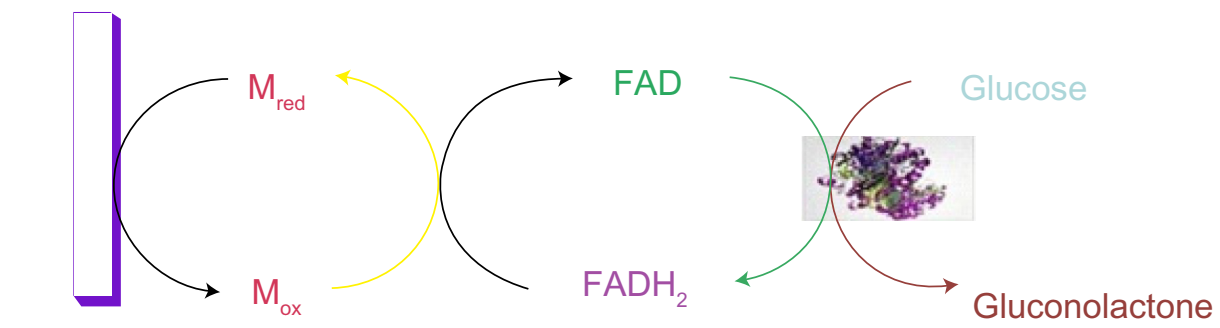

\section{Electrode}

Figure 3 Diagrammatic representation of the second-generation of a glucose biosensor. Abbreviation: FAD, flavin adenine dinucleotide.

\section{Third-generation glucose biosensor}

The third-generation glucose biosensor is advantageous due to the absence of a mediator and involves direct electron transfer between the enzyme and electrode. Conducting organic salts like tetrathiafulvalene-tetracyanoquinodimethane were used for direct electron transfer from enzyme to electrode. ${ }^{18,19}$ Mesoporous electrode materials with increased electrode surface and dynamics are gaining more interest without the difficulties in the usage of mediators and the deficiency of oxygen. ${ }^{20,21}$ The diagrammatic representation of the third-generation glucose biosensor is shown in Figure 4.

\section{Electrodes used in electrochemical biosensors}

Electrodes play an important role in electrochemical biosensors. The detection capacity of the electrochemical biosensor can be affected by the electrode surface dimension, its material, and modifications. ${ }^{22}$ Three different types of electrodes are used in the electrochemical biosensor, ie, reference electrode, working electrode, and auxillary (counter) electrode.

\section{Reference electrode}

Reference electrode is an electrode that resists the changes in the value of its potential and has negligible current.

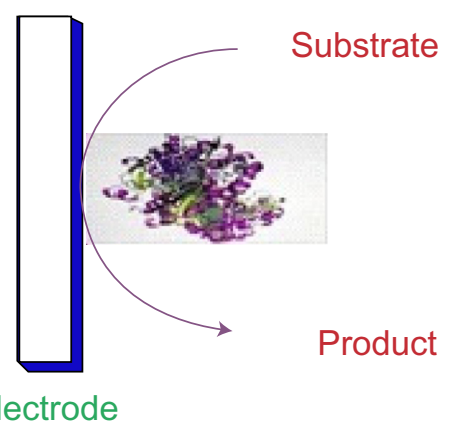

Figure 4 Diagrammatic representation of the third generation of a glucose biosensor.
A good reference electrode is nonpolarizable and has constant potential during the passage of low current.

\section{Working electrode}

It is the electrode on which all the processes of interest take place in an electrochemical system. Working electrode can be referred to as either cathodic or anodic depending on the reaction that takes place at the surface of the working electrode. ${ }^{23-25}$

\section{Auxiliary (counter) electrode}

A platinum wire is generally used as a counter (or auxiliary) electrode because platinum is an inert material and does not affect the behavior of the working electrode.

\section{Important characteristics of the electrochemical biosensor}

Sensitivity of the electrochemical biosensor must be high. Sensitivity is defined as the electrochemical response of the biosensor for a very small change in the analyte concentration, $\mathrm{pH}$, temperature, and so on. The electrochemical biosensor must also be selective in nature. Electrochemical response of the biosensor should be specific for a particular target analyte. Response time of the electrochemical biosensor should be very small so that it can very quickly record any changes that take place in the target analyte. The detection limit of the electrochemical biosensor is such that it can easily detect very low concentrations of the analyte.

\section{Classification of electrochemical biosensor}

Electrochemical biosensors are classified into two types, depending on the type of bioreceptor and transducer used.

\section{On the basis of bioreceptor}

Bioreceptors are the protein molecules that are embedded in the cellular membrane to which target analytes specifically bind. Bioreceptors can be classified into five different types. 
The classification of different types of biosensors is shown in Figure 5.

\section{Enzyme-based bioreceptor}

An enzyme is a large, complex macromolecule consisting largely of proteins that act as powerful catalysts to convert substrates into products. The enzymes used in the biosensor and their mode of action, which involve oxidation or reduction, can be detected electrochemically.

The main reason for the popularity of bioreceptors is the catalytic activity of enzymes and their specific binding capacity. These biosensors utilize enzymes that are specific for the desired molecules. Different types of enzymes were used for the fabrication of biosensors. For example, fructose dehydrogenase enzymes were used for fructose, ${ }^{26}$ alcohol oxidase enzyme for alcohol, ${ }^{27}$ amino acid oxidase for amino acid, ${ }^{28}$ and glucose dehydrogenase for glucose. ${ }^{29}$ The lifetime of a sensor is limited by the stability of the enzyme. The five basic methods of enzyme immobilization are adsorption, microencapsulation, entrapment, cross-linking, and covalent bonding. ${ }^{30}$

\section{Adsorption}

Adsorption is a simple and quick method for manufacturing enzymatic biosensors. It is of two types: physical adsorption (physisorption) and chemical adsorption (chemisorptions). Physisorption is usually weak and involves the formation of van der Waals bonds. Chemisorption is much stronger and involves the formation of covalent bonds.

\section{Microencapsulation}

This method uses an inert membrane to trap the biomaterial for the transducer. The membrane includes cellulose acetate (which excludes proteins and the transportation of interfering species like ascorbate), polycarbonate (a synthetic material that is nonpermselective), collagen (a natural protein), Teflon (a synthetic polymer that is selectively permeable to gases like oxygen), nafion, and polyurethanes.

\section{Entrapment}

A polymeric gel is prepared in a solution containing biomaterial. The enzyme is entrapped within the gel matrix. This can cause barriers to the diffusion of substrate and slowing down of the reaction. The most commonly used gel is polyacrylamide. Conducting polymers (polypyrroles) are used for the electrode.

\section{Cross-linking}

In this method, bifunctional reagents such as glutaraldehyde bind the biomaterial that is chemically bonded to solid supports. It can be a useful method for stabilizing adsorbed biomaterials.

\section{Covalent bonding}

Some functional groups can be covalently bonded to the support matrix (transducer or membrane). The advantage of this method is that the enzyme will not be released during use. In order to protect the active site, the reaction is carried out in the presence of substrate.

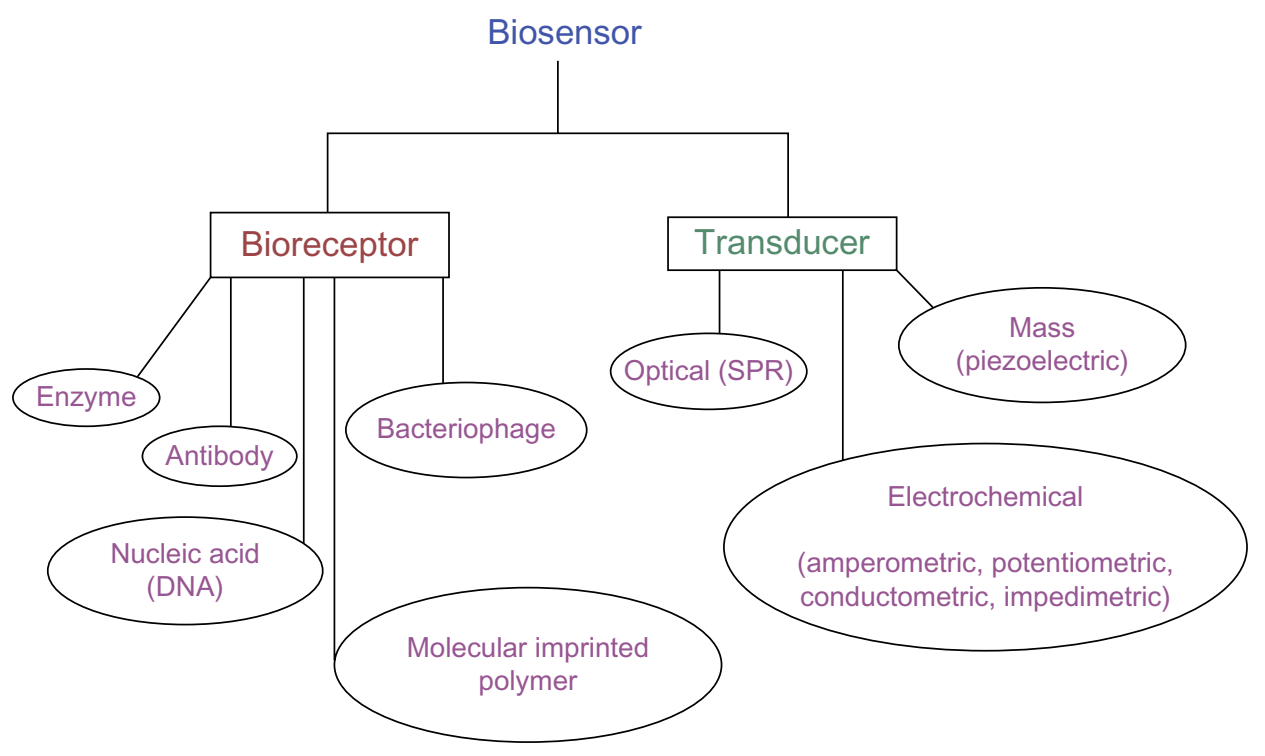

Figure 5 Biosensor classifications and methods. Abbreviation: SPR, surface plasmon resonance. 


\section{Antibody- or antigen-based bioreceptor}

Antibodies are common bioreceptors used in biosensors. The antibodies may be monoclonal, polyclonal, or recombinants depending on the properties and synthesis. ${ }^{31}$ Antibody-antigen-based biosensor is also known as immunosensor. Figure 6 shows a typical antigen-antibody interaction. This type of interaction is similar to lock-and-key interaction in which the antigen will bind to the antibody if it has correct conformation. ${ }^{32}$ Some of the disadvantages of using antibodies in the biosensors are the binding capacity of antibodies affected by the $\mathrm{pH}$ and temperature conditions; and the irreversible antibody-antigen interaction binding they may interrupt. ${ }^{33}$

\section{Nucleic acid-based bioreceptor}

A biosensor that uses nucleic acid as a bioreceptor is known as genosensor. ${ }^{34}$ Nucleic acid analysis has become an important tool for the identification of microorganisms such as pathogens, bacterium, and so on, which are commonly present in food and the environment. ${ }^{35-39}$ The process is based on the principle of complementary base pairing, adenine-thymine, and cytosine-guanine in DNA. If the target nucleic acid sequence is known, complementary sequences can be synthesized, labeled, and then immobilized on the sensor. The hybridization probes can then base pair with the target sequences, generating an optical signal. ${ }^{40}$

\section{Molecular-imprinted polymers-based bioreceptor}

It is a technique of producing artificial recognition sites by forming a polymer around a molecule that can be used as a template. Molecular-imprinted polymers (MIPs) can be synthesized for any analyte molecule and are capable of binding target molecules with affinities. MIPs possess many disadvantages such as the fact that it is very difficult to completely remove the template from MIPs and the imprinted polymer is insoluble. ${ }^{41}$

\section{Bacteriophages-based bioreceptor}

Bacteriophages are viruses that are made of an outer protein coat and inside genetic material (DNA or RNA).

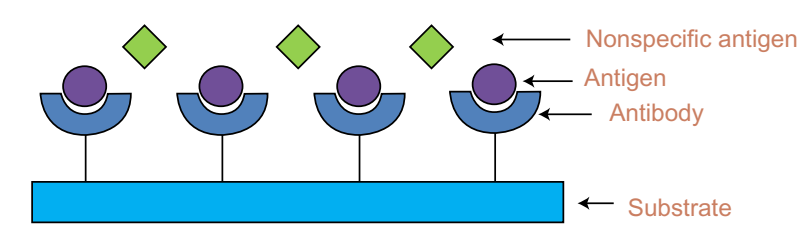

Figure 6 Antigen-antibody interaction taking place at the surface of the transducer.
Bacteriophages are considered as biorecognition elements for the identification of various microorganisms present in food and environment. The viruses can bind to specific receptors and inject their genetic material inside the bacteria. Researchers reported the use of phages as a biorecognition substance for the identification of various pathogens such as Escherichia coli, ${ }^{42}$ Staphylococcus aureus, ${ }^{43}$ and Bacillus anthracis $^{44,45}$ on sensing platforms.

\section{On the basis of transducers}

Transducer plays an important role in the detection process of the biosensor and converts the biological or chemical signal into an electrical signal. Depending upon the type of transducer used, they are classified into optical-, electrochemical-, and mass-based biosensors.

\section{Optical biosensor}

These types of biosensors are based on measuring the changes in the intensity of light and convert light signal into an electrical signal that can be recorded in the form of current or potential. Optical biosensors have gained considerable interest for bacterial pathogen detection due to their sensitivity and selectivity. The most commonly used technique of optical detection is surface plasmon resonance (SPR) for pathogen detection.

\section{SPR-based optical biosensor}

SPR is based on the phenomena of optical illumination of metal surface for the detection of food-borne pathogens. To capture the optical illumination, certain antibodies were immobilized on a thin gold film. The interaction of light with the electrons present in the metal leads to the generation of strong resonance. When the pathogen is bound to the metal surface, there is a shift in the resonance to the higher wavelength and the concentration of bound pathogen is directly proportional to the amount of shift in the resonance. ${ }^{46}$ Figure 7 shows a typical SPR-based biosensor. With the help of SPR technique, diagnosis of pathogens such as E. coli $\mathrm{O} 157: \mathrm{H} 7$ and $S$. aureus using bacteriophage as bioreceptor has been reported. ${ }^{47} \mathrm{~A}$ modified technique was developed for the detection of E. coli $\mathrm{O} 157: \mathrm{H} 7$ at a low concentration of 50 colony forming unit $(\mathrm{CFU}) / \mathrm{mL}$ called long-range surface plasmons in which magnetic NPs were used. ${ }^{48}$ Many researchers use commercially available SPR biosensor for the identification of food-borne pathogens. BIACORE 3000 was used for the detection of Listeria monocytogenes ${ }^{49}$ and Salmonella, ${ }^{50}$ and Spreeta $^{\mathrm{TM}}$ was used for E. coli $\mathrm{O} 157: \mathrm{H} 7.51,52$ 


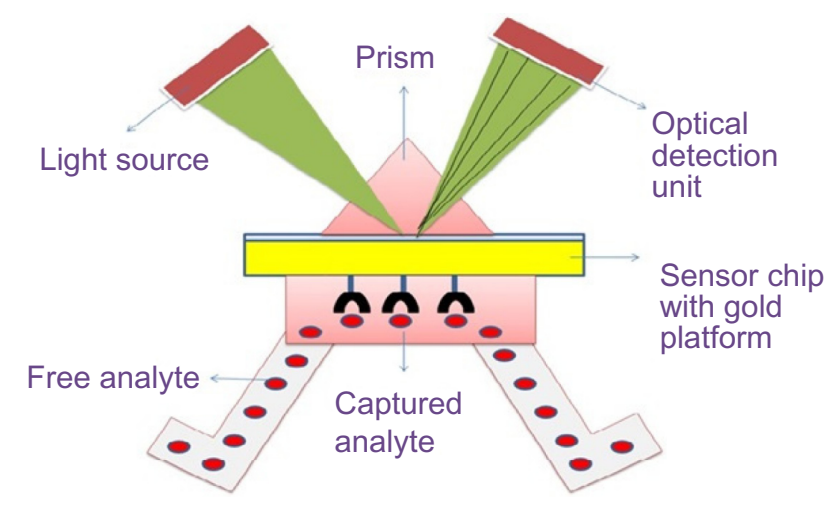

Figure 7 Surface plasmon resonance-based optical biosensor.

\section{Electrochemical biosensor}

The present popularity of the electrochemical biosensor over other biosensors is due to advantages such as low cost, good sensitivity and selectivity, use in turbid media, and miniaturization potential for the detection of food-borne pathogens. ${ }^{53}$ In the electrochemical biosensor, when there is an interaction between the sensor electrodes and the sample analyte, then the changes in the current and potential values are measured. They are classified into amperometric (current), potentiometric (potential), and impedimetric (impedance), which depend on the type of transducer used. ${ }^{54}$

Amperometric transduction is most common in the electrochemical method for the detection of food-borne pathogens. ${ }^{55}$ In an amperometric biosensor, current is produced by the oxidation or reduction of electroactive species at the working electrode (ie, gold, carbon, platinum). The value of current magnitude produced at the surface of working electrode is proportional to the quantity (concentration) of analyte present in the test solution. ${ }^{56}$ Figure 8 shows the pictorial

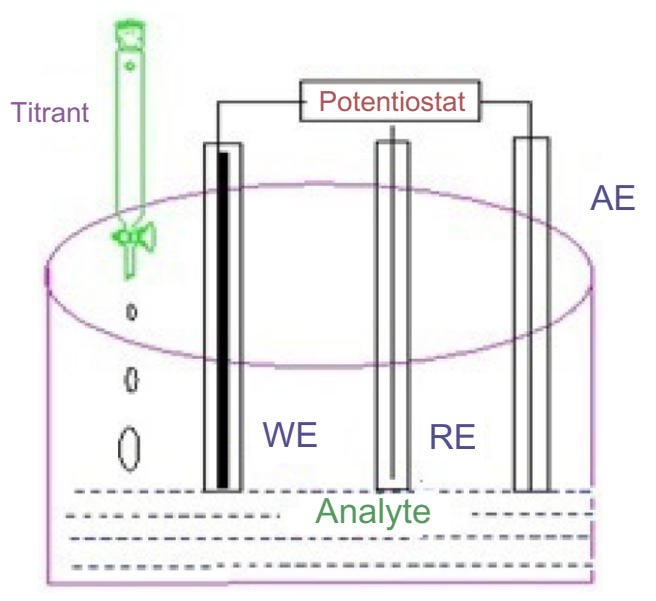

Figure 8 Amperometric biosensor.

Abbreviations: AE, auxiliary electrode; RE, reference electrode; WE, working electrode. representation of a amperometric-based electrochemical biosensor.

Kong et $\mathrm{al}^{57}$ fabricated an amperometric glucose biosensor in which they immobilized GOx on the $\mathrm{ZnO}$ nanotubes using cross-linking method and further detected the amount of glucose in blood samples. Concentration of glucose was found to be $50 \mu \mathrm{M}-12 \mathrm{mM}$ within 3 seconds response time. The sensitivity of the biosensor was found to be $21.7 \mu \mathrm{A} / \mathrm{mM} \mathrm{cm}^{2}$, and its experimental detection limit was found to be $1.0 \mu \mathrm{M}$.

Caib et $\mathrm{al}^{58}$ used two enzymes along with CNTs for the detection of cholesterol for the clinical diagnosis of diseases such as brain thrombosis, arteriosclerosis, and coronary heart disease ${ }^{59,60}$ based on CNTs that were fabricated through layerby-layer method by using bienzyme biosensor (horseradish peroxidase and cholesterol oxidase) and obtained the linear range of cholesterol from 0.18 to $11 \mathrm{mM}$, with a detection limit of $0.02 \mathrm{mM}$.

Yanping et $\mathrm{al}^{61}$ developed an amperometric biosensor for the organophosphate pesticide with a detection limit of $0.5 \mathrm{ng} / \mathrm{mL}$ by modifying glassy carbon electrode with acetylcholinesterase immobilized on porous reduced graphene oxide. For the detection of Campylobacter jejuni in chicken wash matrix, an amperometric biosensor was developed with a detection range of $10^{3}-10^{7} \mathrm{CFU} / \mathrm{mL} .{ }^{62}$ Detection of algal toxins, such as domoic acid and microcystin-LR, in food chain was reported. ${ }^{63-65}$ Lata et al $^{28}$ fabricated an amperometric biosensor by covalently immobilizing an L-amino acid oxidase onto carbon nanotube/zinc oxide nano particles/ polyaniline (MWCNT/ZnONPs/PANI)/Au electrode that gives a broad range from 0.001 to $70 \mathrm{mM}$ with a detection limit of $0.35 \mu \mathrm{m}$ and a response time of 4 seconds.

Jesus et $\mathrm{l}^{66}$ fabricated an amperometric glucose biosensor based on layer-by-layer film formed between the silsesquioxane polyelectrolyte and phthalocyanine that was modified with GOx and a film of nafion. Current shows linearity with a glucose concentration range of $1-10 \mathrm{mmol} / \mathrm{L}$ with a detection limit of $0.16 \mathrm{mmol} / \mathrm{L}$ and a sensitivity of $1.397 \times 10^{-7} \mu \mathrm{A}(\mathrm{mmol} / \mathrm{L})$.

In a potentiometric biosensor, the biorecognition process is converted into a potential signal. This sensor uses ion-selective field effect transistors (ISFETs) and lightaddressable potentiometric sensors (LAPSs).

In order to increase electrical conductivity in ISFETs, an electric field is used to generate excess charge in semiconductor substrate. ${ }^{67}$ In a potentiometric immunosensor, enzyme-labeled antibodies such as GOx, urease, or alkaline phosphatases are used, which are able to change either $\mathrm{pH}$ 
or ionic strength during the detection of microorganisms present in food sample. ${ }^{68}$ LAPS evolved from ISFET by combining potentiometry with optical sensor for the detection of food-borne pathogens. Figure 9 shows a typical potentiometric biosensor having working electrode composed of CNT, polyvinylpyrilidon, NP, and potassium chloride $(\mathrm{KCl})$ with asbestos membrane.

Due to simultaneous detection of several analytes, semiconductor-based LAPS was used because of its small size and multichannel arrangement. ${ }^{69}$ LAPS measures a photocurrent produced by a light-emitting diode.

Singh et $\mathrm{a}^{69}$ used LAPS for the detection of Yersinia pestis and Bacillus globigii spores with a limit of detection (LOD) of 10 cells/spores per sample, and later Dill et al ${ }^{70}$ used LAPS for the detection of Salmonella typhimurium at a low level of colony forming unit, ie, 119 CFUs. ${ }^{70}$

Ahuja et $\mathrm{al}^{71}$ developed a potentiometric urea biosensor based on bovine serum albumin embedded on the surface of modified polypyrrole film. The electrode shows a linear response of $6.6 \times 10^{-6}$ to $7.5 \times 10^{-4} \mathrm{M}$ urea in $70-90$ seconds.

Conductometric biosensor is generally based on the conductance measurement, that is, whenever a change in the ionic concentration of an analyte occurs, there is a subsequent change in the electrical conductivity of the solution or changes in the flow of current. ${ }^{72}$ The microbial metabolism changes occur in the medium or analyte, which result in an increase in both capacitance and conductance, causing a decrease in impedance..$^{73}$ Therefore, conductance, capacitance, impedance and resistance are interrelated with each other, but they only differ in ways of monitoring the test system. ${ }^{74,75}$ Tahir and Alocilja ${ }^{76}$ developed a conductometric

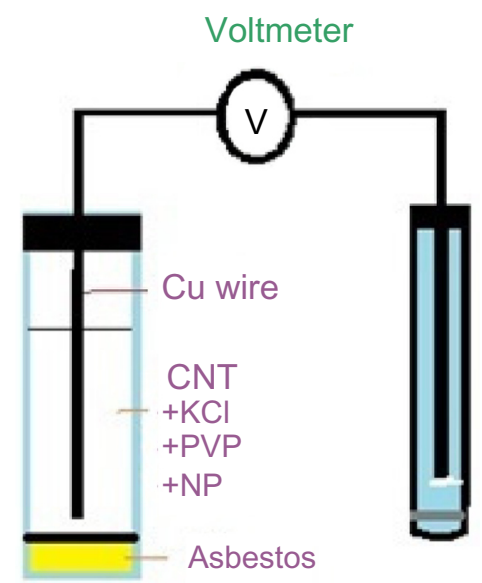

Working electrode Reference electrode

Figure 9 Potentiometric biosensor.

Abbreviations: $\mathrm{Cu}$, copper; $\mathrm{CNT}$, carbon nanotube; $\mathrm{KCl}$, potassium chloride; PVP, polyvinylpyrilidon; NP, nanoparticle. biosensor for the detection of E. coli $0157: \mathrm{H} 7$ and Salmonella food pathogens in 10 minutes with an LOD of $81 \mathrm{CFU} / \mathrm{mL}$.

\section{Nanomaterials-based electrochemical biosensors}

Nanomaterials, such as magnetic NPs, carbon nanostructures, and quantum dots, have important components to enhance performance in terms of lower detection limit, and higher sensitivity and faster electron transfer. The use of metal NPs and graphene is common practice to increase surface area and conductivity of the electrochemical biosensor. The addition of metal NPs in the working electrode increases sensitivity and current signal response time of the electrochemical biosensor. Huang et $\mathrm{al}^{17}$ have reported the application of CNTs for crystallization of proteins and building of bioreactors and biosensors. When titanium dioxide NPs combined with CNTs significantly increase disinfectant properties against Bacillus cereus spores, ${ }^{78}$ Ali et al ${ }^{79}$ have reported a gold NPs sensor for the detection of E. coli $\mathrm{O} 157: \mathrm{H} 7$ in feed samples.

\section{Application of electrochemical biosensors for food safety}

The essential requirement of the food industry is that the food supplied in the market should be $100 \%$ safe and of very good quality. For this, the food industry should perform different food analysis methods and different stages of quality checks to ensure the quality and safety of foods. Other concerns of the food industry include increasing the product yield, optimizing energy input, monitoring the food processing, and to raise the food processing automation level. Proper packing of the food is also essential in order to avoid environmental contamination during transport and storage of the food. Determination of chemical and biological contaminants in food is of importance for ensuring healthy nutrition for people. Salmonella, L. monocytogenes, C. jejuni, B. cereus, Vibrio cholerae, and E. coli, and so on are the common pathogens that contaminate food. Hence, it is very important to detect these microbial contaminants using rapid, sensitive, specific, and inexpensive methods of analysis. This goal of the food industry can be achieved by the use of electrochemical biosensors for the detection of chemical and biological contaminants in foods. Electrochemical biosensors provide rapid, specific, and inexpensive food sample analysis.

Table 1 summarizes the response time, LOD, sensitivity, and response time reported by different researchers for the detection of analyte present in food samples. An amperometric detection of $E$. coli $\mathrm{O} 157: \mathrm{H} 7$ was reported in 25 minutes 
Table I Some examples of electrochemical biosensors used in food analysis

\begin{tabular}{|c|c|c|c|c|c|c|}
\hline $\begin{array}{l}\text { Electrochemical } \\
\text { biosensor }\end{array}$ & Analyte & Samples & Limit of detection & Sensitivity & Response time & Reference \\
\hline Amperometric & Fructose & $\begin{array}{l}\text { Honey, apple juice, } \\
\text { orange juice }\end{array}$ & - & $0.62 \pm 0.10 \mathrm{nA} / \mu \mathrm{M}$ & - & 26 \\
\hline Electrochemical & Tryptamine & Real samples & $7.4 \times 10^{-8} \mathrm{~mol} / \mathrm{L}$ & - & - & 85 \\
\hline Electrochemical & Glucose & Real samples & $\mathrm{I}-10 \mathrm{mM}$ & $5.03 \mu \mathrm{A} / \mathrm{mM}$ & 3.0 seconds & 86 \\
\hline Amperometric & Glucose & - & $0.14 \mu \mathrm{m}$ & $2.9 \mathrm{mAcm} / \mathrm{mM}$ & - & 87 \\
\hline Amperometric & Polyphenols & Red wine & $1.0 \times 10^{-6} \mathrm{M}$ & $0.0566 \mathrm{~mA} / \mathrm{M}$ & - & 88 \\
\hline Conductometric & $\begin{array}{l}\text { Heavy metal ions } \\
\left(\mathrm{Zn}^{2+} \text { and } \mathrm{Cd}^{2+}\right)\end{array}$ & Water & $10 \mathrm{ppb}$ & $30 \mathrm{~m}$ & - & 89 \\
\hline Electrochemical & Escherichia coli & Surface water & $3 \mathrm{CFU} / 10 \mathrm{~mL}$ & - & - & 90 \\
\hline Electrochemical & Staphylococcus epidermidis & - & $1.0 \times 10^{6} \mathrm{CFU} / \mathrm{mL}$ & - & & 91 \\
\hline Electrochemical & Salmonella typhimurium & Chicken carcass wash & $10^{2} \mathrm{CFU} / \mathrm{mL}$ & - & 15 minutes & 92 \\
\hline Electrochemical & Listeria monocytogenes & Milk & $10^{2} \mathrm{CFU} / \mathrm{mL}$ & - & $3-4$ hours & 93 \\
\hline Electrochemical & Campylobacter jejuni & $\begin{array}{l}\text { Culture and chicken } \\
\text { carcass wash water }\end{array}$ & $10^{3} \mathrm{CFU} / \mathrm{mL}$ & - & $2-3$ hours & 62 \\
\hline
\end{tabular}

Notes: Real samples of Tryptamine used were tomato juice and banana pulp. Real samples of glucose used were grape, honey and watermelon; hyphens (-) represent data not available.

Abbreviation: CFU, colony forming unit.

with an LOD of 5,000 cells $/ \mathrm{mL} .{ }^{80}$ Xiang et $\mathrm{al}^{81}$ fabricated an electrochemical immunosensor for the detection of Salmonella with the help of gold NPs dispersed in chitosan and found a low detection limit of 5.0 CFU/mL. Another important application of the electrochemical DNA biosensor for the detection of $S$. aureus nuc gene sequence was found in the concentration range of $1.0 \times 10^{-13}-1.0 \times 10^{-6} \mathrm{~mol} / \mathrm{L}$ with an LOD of $3.23 \times 10^{-14} \mathrm{~mol} / \mathrm{L}(3 \sigma) .{ }^{82}$ Girousi et al ${ }^{83}$ fabricated a mitochondria-based amperometric biosensor for the determination of L-glutamic acid in the range of $10 \pm 100 \mathrm{mM}$ with a sensitivity of $0.021 \mu \mathrm{A} / \mathrm{mM}$. Girousi et al ${ }^{84}$ again fabricated a mitochondria-based amperometric biosensor for the determination of $\mathrm{L}$-succinic acid in the range of $0.05-0.4 \mathrm{mM}$ with a sensitivity of $0.388 \mu \mathrm{A} / \mathrm{mM}$, and the detection limit was found to be $0.02 \mathrm{mM}$.

\section{Future perspective}

Much has been achieved in the field of electrochemical biosensors for food safety, however more needs to be done in the near future. Future work should be focused on the development of a novel biosensor in which power consumption must be reduced and more efficient power sources (batteries, capacitors, and so on) must be developed and fixed into biological detection systems to reduce the size and weight of the system and to increase system utility. A handheld and easily portable and smart electrochemical biosensor is needed so that detection of chemical and biological toxins can be made in the field of actual production so that proper monitoring of the food samples can be done. Future research should focus on the development of biosensors that may help fight against the disease-causing food-borne pathogens. Nanocomposites are receiving increasing interest for sensor construction in recent years. Handling of biosensors should be made simple so that even someone without specialized knowledge can use it without the help of qualified persons. Multifunctional and versatile biosensing systems are required for the analysis of multiple analytes using a single device. A more sensitive biosensor that is capable of detecting the nanomolar ranges in the field of food industry, environmental monitoring, and medical diagnosis will certainly prove fruitful.

\section{Conclusion}

Biosensor-based devices have become an important part of the equipment used in laboratories to detect biological response. In spite of having developed a number of biosensors for detecting food-borne pathogens, it is still a challenge to create biosensors for the reliable and effective determination of microorganisms in real food samples. Conventional methods (enzyme-linked immunosorbent assay, polymerase chain reaction) for detecting food-borne pathogens are good but need well-trained persons, involve tedious procedures, and take a long time to show results. Ideal biosensors will have great potential to achieve better results and detect multiple pathogens in a very short time. Electrochemical biosensors have great potential in the future following further improvements.

\section{Disclosure}

The authors report no conflicts of interest in this work.

\section{References}

1. Ivnitski D, Hamid IA, Atanasov P, et al. Biosensors for detection of pathogenic bacteria. Biosens Bioelectron. 1999;14:599-624.

2. Viswanathan S, Radecki J. Nanomaterials in electrochemical biosensors for food analysis. Pol J Food Nutr Sci. 2008;58:157-164. 
3. Banica GF. Chemical Sensors and Biosensors: Fundamentals and Applications. Hoboken, NJ: John Wiley and Sons; 2012:576.

4. Thakur MS, Ragavan KV. Biosensor in food processing. J Food Sci Technol. 2013;50:625-641.

5. Lopez BP, Merkoci A. Nanomaterials based biosensors for food analysis applications. Trends Food Sci Tech. 2011;22:625-639.

6. Clark CL, Lyon C. Electrode systems for continuous monitoring in cardiovascular surgery. Ann N Y Acad Sci. 1962;102:29-45.

7. Wang J. Glucose biosensors: 40 years of advances and challenges. Electroanalysis. 2001;13:983-989.

8. Updike S, Hicks G. The enzyme electrode. Nature. 1967;214:986.

9. Guilbault G, Lubrano G. An enzyme electrode for the amperometric determination of glucose. Anal Chim Acta. 1973;64:439.

10. Wang J. Electrochemical glucose biosensors. Chem Rev. 2008;108: 814-825.

11. Wiley J and Sons. Chemical mechanism in enzyme catalysis. A Practical Introduction to Structure, Mechanism and Data Analysis. Hoboken, NJ: Wiley J and Sons; 2000:146-150.

12. Putzbach W, Ronkainen NJ. Immobilization techniques in the fabrication of nanomaterials based electrochemical biosensor - a review. Sensors (Basel). 2013;13(4):4811-4840.

13. Degani Y, Heller A. Electrical wiring of redox enzymes. Acc Chem Res. 1992;23:128-134.

14. Marcus RA, Sutin N. Electron transfers in chemistry and biology. Biochim Biophys Acta. 1985;811:265-322.

15. Liu J, Wang J. Improved design for the glucose biosensor. Food Tech Biotech. 2001;39:55-58.

16. Yoo EH, Lee SY. Glucose biosensors: an overview of use in clinical practice. Sensors (Basel). 2010;10:4558-4576.

17. Zhu Z, Gancedo L, Flewitt AJ, et al. A critical review of glucose biosensors based on carbon nanomaterials: carbon nanotubes and graphene. Sensors (Basel). 2012;12:5996-6022.

18. Albery W, Bartlett PN, Craston DH. Amperometric enzyme electrodes part-II Conducting salts as electrode material for the oxidation of glucose oxidase. J Electroanal Chem. 1985 194-223.

19. Palmisano F, Zambonin PG, Centonze D, et al. A disposable, reagentless, third-generation glucose biosensor based on overoxidized poly(pyrrole) tetrathiafulvalene-tetracyanoquinodimethane composite. Anal Chem 2002;74:5913.

20. Khan GF, Ohwa M, Wernet W. Design of a stable charge transfer complex electrode for a third-generation amperometric glucose sensor. Anal Chem. 1996;68:2939-2945.

21. Bao SJ, Li CM, Zang JF, et al. New nanostructured TiO2 for direct electrochemistry and glucose sensor applications. Adv Funct Mater. 2008;18:591-599.

22. Koyun A, Ahlatcioglu E, Ipek YK. Biosensors and their principles. In: Kara S, editor. A Roadmap of Biomedical Engineers and Milestones. Rijeka: Intech; 2012:115-142.

23. Kissinger P, Heineman WR. Laboratory Techniques in Electroanalytical Chemistry. 2nd ed. New York, NY: Marcel Dekker; 1996.

24. Allen BJ, Faulkner LR. Electrochemical Methods: Fundamentals and Applications. 2nd ed. Philadelphia, PA: Wiley; 2002.

25. Zoski CG. Handbook of Electrochemistry. Philadelphia, PA: Elsevier Science; 2007

26. Trivedi UB, Lakshminarayanaa D, Kothari IL, et al. Amperometric fructose biosensor based on fructose dehydrogenase enzyme. Sensor Actuat B Chem. 2009;136:45-51.

27. Hammerle M, Hilgert K, Horn MA, et al. Analysis of volatile alcohols in apple juices by an electrochemical biosensor measuring in the headspace above the liquid. Sensor Actuat B Chem. 2011;158:313-318.

28. Lata S, Batra B, Singala N, et al. Construction of amperometric L-amino acid biosensor based on L-amino acid oxidase immobilized onto ZnONPs/c-MWCNT/PANI/AuE. Sensor Actuat B Chem. 2013;188: 1080-1088.

29. Liang B, Liang L, Tang XJ, et al. Microbial surface display of glucose dehydrogenase for amperometric glucose biosensor. Biosens Bioelectron. 2013;45:19-24.
30. Eggins BR. Sensing elements. Chemical Sensors and Biosensors. Chichester: Wiley; 2010:98-102.

31. Sharma H, Agarwal M, Goswami M, et al. Biosensors: tool for food borne pathogen detection. Vet World. 2013;6:968-973.

32. Willis JR, Briney BS, DeLuca SL, et al. Human germline antibody gene segments encode polyspecific antibodies. PLoS Comput Biol. 2013;9: e1003045.

33. Marazuela M, Bondi MM. Fiber-optic biosensors - an overview. Anal Bioanal Chem. 2002;372:664-682.

34. Palchetti I, Mascini M. Biosensor technology: a brief history. Sensors and Microsystems. Berlin: Springer; 2010;54:15-23.

35. Farabullini F, Lucarelli F, Palchetti I, et al. Disposable electrochemical genosensor for the simultaneous analysis of different bacterial food contaminants. Biosens Bioelectron. 2007;22:1544-1549.

36. Gier MJL, Scholin CA, Fell JW, et al. An electrochemical RNA hybridization assay for detection of the fecal indicator bacterium Escherichia coli. Mar Pollut Bull. 2005;50:1251-1261.

37. Liao JC, Mastali M, Gau V, et al. Use of electrochemical DNA biosensors for rapid molecular identification of uropathogens in clinical urine specimens. J Clin Microbiol. 2006;44:561-570.

38. Castro RM, Alvarez NDLS, Castanon MJL, et al. Structured nucleic acid probes for electrochemical devices. Electroanalysis. 2009;21: 2077-2090.

39. Yeung SW, Lee TMH, Cai H, et al. A DNA biochip for on-the-spot multiplexed pathogen identification. Nucl Acids Res. 2006;34:e118.

40. Velusamy V, Arshak K, Korostynska O, et al. An overview of foodborne pathogen detection: in the perspective of biosensors. Biotech Adv. 2010;28:232-254.

41. Haupt K, Mosbach K. Molecularly imprinted polymers and their use in biomimetic sensors. Chem Rev. 2000;100:2495-2504.

42. Singh A, Glass N, Tolba M, et al. Immobilization of bacteriophages on gold surfaces for the specific capture of pathogens. Biosens Bioelectron. 2009;24:3645-3651.

43. Balasubramanian S, Sorokulova IB, Vodyanoy VJ, et al. Lytic phage as a specific and selective probe for detection of Staphylococcus aureus a surface plasmon resonance spectroscopic study. Biosens Bioelectron. 2007;22:948-955.

44. Huang S, Li SQ, Yang H, et al. Optimization of phage-based magnetoelastic biosensor performance. Sens Transducers J. 2008;3:87-96.

45. Xie F, Yang H, Li S, et al. Amorphous magnetoelastic sensors for the detection of biological agents. Intermetallics. 2009;17:270-273.

46. Arora P, Sindhu A, Dilbaghi N, et al. Biosensors as innovative tools for the detection of food borne pathogens. Biosens Bioelectron. 2011;28:1-12.

47. Tawil N, Sacher E, Mandeville R, et al. Surface plasmon resonance detection of $E$. coli and methicillin-resistant $S$. aureus using bacteriophages. Biosens Bioelectron. 2012;37:24-29.

48. Wang Y, Knoll W, Dostalek J. Bacterial pathogen surface plasmon resonance biosensor advanced by long range surface plasmons and magnetic nanoparticle assays. Anal Chem. 2012;84:8345-8350.

49. Leonard P, Hearty S, Quinn J, et al. A generic approach for the detection of whole Listeria monocytogenes cells in contaminated samples using surface plasmon resonance. Biosens Bioelectron. 2004;19: 1331-1335.

50. Bokken G, Corbee RJ, Knapen FV, et al. Immunochemical detection of Salmonella group B, D and E using an optical surface plasmon resonance biosensor. FEMS Microbiol Lett. 2003;222:75-82.

51. Meeusen CA, Alocilja EC, Osburn WN. Detection of E. coli O157: H7 using a miniaturized surface plasmon resonance biosensor. Trans ASAE. 2005;48:2409-2416.

52. Waswa J, Irudayaraj J, Roy CD. Direct detection of E. Coli O157: H7 in selected food systems by a surface plasmon resonance biosensor. $L W T$ Food Sci Technol. 2007;40:187-192.

53. Palchetti I, Mascini M. Electroanalytical biosensors and their potential for food pathogen and toxin detection. Anal Bioanal Chem. 2008;391:455-471.

54. Lazcka O, Campo FJD, Munoz FX. Pathogen detection: a perspective of traditional methods and biosensors. Biosens Bioelectron. 2007;22: $1205-1217$. 
55. Ghindilis AL, Atanasov P, Wilkins P, et al. Immunosensors: electrochemical sensing and other engineering approaches. Biosens Bioelectron. 1998; $13: 113-131$

56. Zhang X, Ju H, Wang J. Electrochemical Sensors, Biosensors and Their Biomedical Applications. Waltham, MA: Academic Press is an imprint of Elsevier; 2008.

57. Kong T, Chen Y, Ye Y, et al. An amperometric glucose biosensor based on the immobilization of glucose oxidase on the $\mathrm{ZnO}$ nanotubes. Sensor Actuat B Chem. 2009;138:344-350.

58. Caib X, Gao X, Wang L, et al. A layer-by-layer assembled and carbon nanotubes/gold nanoparticles-based bienzyme biosensor for cholesterol detection. Sensor Actuat B Chem. 2013;181:558-575.

59. Arya SK, Datta M, Malhotra BD. Recent advances in cholesterol biosensor. Biosens Bioelectron. 2008;23:1083-1100.

60. Lee YJ, Park JY. Nonenzymatic free-cholesterol detection via a modified highly sensitive macroporous gold electrode with platinum nanoparticles. Biosens Bioelectron. 2010;26:1353-1358.

61. Yanping L, Yunfei B, Gaoyi H, et al. Porous-reduced graphene oxide for fabricating an amperometric acetylcholinesterase biosensor. Sensor Actuat B Chem. 2013;185:706-712.

62. Che Y, Li Y, Slavik M. Detection of Campylobacter jejuni in poultry samples using an enzyme-linked immunoassay coupled with an enzyme electrode. Biosen Bioelectron. 2001;16:791-797.

63. Campas M, Marty JL. Highly sensitive amperometric immunosensors for microcystin detection in algae. Biosen Bioelectron. 2007;22: 1034-1040.

64. Micheli L, Radoi A, Guarrina R, et al. Disposable immunosensor for the determination of domoic acid in shellfish. Biosen Bioelectron. 2004;20:190-196.

65. Kania M, Kreuzer M, Moore E, et al. Development of polyclonal antibodies against domoic acid for their use in electrochemical biosensors. Anal Lett. 2003;36:1851-1863.

66. Jesus CGD, Lima D, Santos V, et al. Glucose biosensor based on the highly efficient immobilization of glucose oxidase on layerby-layer films of silsesquioxane polyelectrolyte. Sensor Actuat B Chem. 2013;186:44-51.

67. Bergveld P. Thirty years of ISFETOLOGY: what happened in the past 30 years and what may happen in the next 30 years. Sens Actuat B Chem. 2003;88:1-20.

68. Kumar H, Rani R. Development of biosensors for the detection of biological warfare agents: its issues and challenges. Sci Prog. 2013;96: 294-308.

69. Singh S, Solanki PR, Malhotra BD. Covalent immobilization of cholesterol esterase and cholesterol oxidase on polyaniline films for application to cholesterol biosensor. Anal Chim Acta. 2005;568:126-132.

70. Dill K, Song JH, Blomdahl JA, et al. Rapid sensitive and specific detection of whole cells and spores using the light-addressable potentiometric sensor. J Biochem Biophys Methods. 1997;34:161-166.

71. Ahuja T, Mir IA, Kumar D, Rajesh N. Potentiometric urea biosensor based on BSA embedded surface modifiedpolypyrrole film. Sens Actuat B Chem. 2008;134:140-145.

72. Rogers KR, Mascini M. Biosensors for field analytical monitoring. Field Analyt Chem Tech. 1998;2:317-331.

73. Invitski D, Hamid IA, Atanasov P, et al. Application of electrochemical biosensors for detection of food pathogenic bacteria. Electroanalysis. 2002; $12: 317-325$.

74. Silley P, Forsythe S. Impedance microbiology - a rapid change for microbiologists. J Appl Bacteriol. 1996;80:233-243.
75. Milner KR, Brown AP, Allsopp DWE, et al. Dielectrophoretic classification of bacteria using differential impedance measurements. Electron Lett. 1998;34:66-68.

76. Tahir ZM, Alocilja EC. Disposable biosensor for pathogen detection in fresh produce samples. Biosyst Eng. 2004;88:145-151.

77. Huang W, Taylor S, Fu K, et al. Attaching proteins to carbon nanotubes via diimideactivated amidation. Nano Lett. 2000;2:311-314.

78. Krishna V, Pumprueg S, Lee SH, et al. Photocatalytic disinfection with titanium dioxide coated multi-wall carbon nanotubes. Proc Safety Environ Prot. 2005;83:393-397.

79. Ali MA, Eldin TA, Moghazy ME, et al. Detection of E. coli O157:H7 in feed samples using gold nanoparticles sensor. Int J Curr Microbiol App Sci. 2014;3(6):697-708.

80. Brewster JD, Mazenko RS. Filtration capture and immunoelectrochemical detection for rapid assay of Escherichia coli O157:H7. J Immun Methods. 1998;211:1-8.

81. Xiang C, Li R, Adhikari B, et al. Sensitive electrochemical detection of Salmonella with chitosan-gold nanoparticles composite film. Talanta. 2015;140:122-127.

82. Sun W, Wang X, Wang W, et al. Electrochemical DNA sensor for Staphylococcus aureus nuc gene sequence with zirconia and graphene modified electrode. J Solid State Electrochem. 2015;19:2431-2438.

83. Girousi ST, Pantazaki AA, Voulgaropoulos AN. Mitochondria-based amperometric biosensor for the determination of L-glutamic acid. Electroanal. 2001;13:243-245.

84. Girousi ST, Apostolidou CD, Pantazaki AA, et al. Mitochondria-based amperometric biosensor for the determination of L-succinic acid. Analyt Lett. 2001;34:1079-1086.

85. Xing X, Liu S, Yu J, et al. Electrochemical sensor based on molecularly imprinted film at polypyrrole-sulfonated graphene/hyaluronic acidmultiwalled carbon nanotubes modified electrode for determination of tryptamine. Biosen Bioelectron. 2012;31:277-283.

86. Gomathi P, Kim MK, Park JJ, et al. Multiwalled carbon nanotubes grafted chitosan nanobiocomposite: a prosperous functional nanomaterials for glucose biosensor application. Sens Actuat B Chem. 2011;155: 897-902.

87. Cherevko $\mathrm{S}$, Chung $\mathrm{CH}$. The porous $\mathrm{CuO}$ electrode fabricated by hydrogen bubble evolution and its application to highly sensitive nonenzymatic glucose detection. Talanta. 2010;80:1371-1377.

88. Gomes SASS, Nogueira JMF, Rebelo MJF. An amperometric biosensor for polyphenolic compounds in red wine. Biosen Bioelectron. 2004;20: 1211-1216.

89. Chouteau C, Dzyadevych S, Durrieu C, et al. A bi-enzymatic whole cell conductometric biosensor for heavy metal ions and pesticides detection in water samples. Biosens Bioelectron. 2005;21:273-281.

90. Zhang X, Geng P, Liu H, et al. Development of an electrochemical immunoassay for rapid detection of $E$. coli using anodic stripping voltammetry based on $\mathrm{Cu} @$ Au nanoparticles as antibody labels. Biosens Bioelectron. 2009;24:2155-2159.

91. Karasinski J, White L, Zhang Y, et al. Detection and identification of bacteria using antibiotic susceptibility and a multi-array electrochemical sensor with pattern recognition. Biosens Bioelectron. 2007;22: 2643-2649.

92. Dill K, Stanker LH, Young CR. Detection of salmonella in poultry using a silicon chip-based biosensor. J Biochem Biophys Methods. 1999;41: 61-67.

93. Crowley EL, Sullivan CKO, Guilbault GG. Increasing the sensitivity of Listeria monocytogenes assays: evaluation using ELISA and amperometric detection. Analyst. 1999;124:295-299. 
Nanobiosensors in Disease Diagnosis

Dovepress

\section{Publish your work in this journal}

Nanobiosensors in Disease Diagnosis is an international, peer-reviewed, open access journal publishing original research, reports, reviews and commentaries including but not confined to: Diagnosis of diseases including cancer, cardiovascular, infectious diseases; Molecular modeling in diagnosis; Enzyme and membrane technologies; and quantum dot fluorescence technologies for monitoring toxins and pathogens. The manuscript management system is completely online and includes a very quick and fair peer-review system, which is all easy to use. Visit $\mathrm{http}: / /$ www.dovepress.com/testimonials.php to read real quotes from published authors.

Submit your manuscript here: http://www.dovepress.com/nanobiosensors-in-disease-diagnosis-journal 